\title{
Menace of Waste Dumping Along Median Strips and Drainage in Ogun State: a Development Communication Approach
}

\author{
EVARISTUS ADESINA ${ }^{1}$, OLADOKUN OMOJOLA ${ }^{2}$, LANRE AMODU $^{3}$ BABATUNDE $^{\text {BA }}$ \\ ADEYEYE ${ }^{4}$, DARLYNTON YARTEY ${ }^{5}$ \\ ${ }^{12345}$ Department of Mass Communication \\ Covenant University, Ota \\ NIGERIA
}

Abstract: Waste dumping along the median strips and drainages is fast becoming a norm among residents of Ogun State. This study sought to investigate the reasons why residents dump refuse along the median strips ; to what extent are they aware of the statutory provisions against the menace as well as find how their knowledge of the health and environmental consequences of Waste Dumping along the median Strip and Drainages. Theory of planned behaviour connected to the research area was reviewed thereby clarifying the main topic and aiding the data collection. The research methodology of survey and in-depth interview were used in the study. An interview was conducted with the Permanent Secretary Cabinet Matter in the Ogun State Government. A structured designed questionnaire was administered to a randomly selected sample of 300 respondents. 150 respondents each in Idiroko Expresss Road Ota, Ogun State and the Adatan/Lafenwa Road, Abeokuta, Ogun State. The result of the study revealed that Government, believes that the practice of the people is unjustifiable, describing it as an act of total indiscipline. Although residents of Ogun State are aware of the wrongness of dumping waste along the median strips and drainages, results from the findings of the survey revealed that 54\% of the respondents attributed illicit waste dumping act to the long distance of waste containers, 56.3\% related their actions to non-availability of waste dump site. The study further shows that $80.2 \%$ of the sampled population expressed knowledge of the existence of laws against dumping of waste along median strips and drainages. The study therefore concluded that on the need for an urgent shift from Mongolic to Dialogic communication in curbing the deepening behavioural pattern of dumping waste along the median strips and drainages by residents of Ogun State.

Keywords: Menace, waste, dumping, median strip, drainages, development communication Received: March 26, 2020. Revised: November 23, 2020. Accepted: December 31, 2020. Published: January 20, 2021.

\section{Introduction}

Waste dumping across the median and drainages is fast becoming a cultural practice across major cities and towns of Ogun State. At different medians in the state are heaps of refuse from households and commercial shopping centres littering roads. Worst of this menace is the act of dumping refuse in the drainages during dry and raining seasons. Wastes, according to [1], are refuse (empty containers, papers rubbish) sewage (faeces, water urine) and industrial waste (chemical nuclear) that result from the manufacturing of certain substances, materials and equipment. Oyelola and Babatunde [2] further describes waste as any material lacking direct value to the user and so must be disposed of. The collection and disposal mechanism of waste has however been challenging, as observed by Donevska, et al. 
[3] who noted that solid waste collection and disposal are among the most serious threats to waste management in most cities.

Uncontrolled waste dumping across medians and drainages however has brought unprecedented consequences on the health of people residing or transacting business around these polluted areas. The prevalence of tetanus, malaria, cholera, and diarrhoea are so common in many African countries linked to unsanitary conditions caused by waste which usually scattered around [4].

Though flooding is a common national problem caused by blockage of waterways as a result of high water density, its effect on lives and property is usually more detrimental due to unmanaged negative human activities of waste dumping in drainages [5-7]. Government at all levels; federal, state and local, civil society groups, academics, have in the past, developed policies and strategies in theories and practice to solve this challenge [8-10]. However, the environmental problem of unmanaged waste dumping and its many effects is increasing. Central to this increasing negative culture by people and the many policies different groups such as health experts and other stakeholders have postulated is communication. That is, strategic role communication can play in sensitising people on waste dumping, existing laws and effect, health and environmental consequences.

Ogun State, being one of the fast industrialising states in Nigeria, needs to develop a strategic plan for effective and adequate waste dumping management. This study therefore seeks to examine the menace of waste dumping along the median strips ad drainages with a view to finding out the causes thus developing a new communication model to solve the issue.

\section{Statement of the Research Problem}

Over the years, there has been a sharp rise in improper and indiscriminate waste dumping practice along the road medians and drainages by residents in Ogun State [11-13]. This can be un- arguably traced to a number of reasons including the increasing population growth rate, increasing urbanisation, industrialisation and economic growth in the state. Regrettably however this act is at an exponential rate leading to what can be described as dirty, unsanitary, and aesthetically displeasing. Waste generation cannot be stopped, but has to be managed [14-16]. However, in Ogun State, waste is inevitably generated, but wrongfully managed by both government and the people. Unmanaged wasted dumping is a huge problem which is in need of attention, because of its implication on the environment, especially as regards soils, vegetation and water. In most towns and cities, it is common to see more of these wastes indiscriminately littered. Littering is a threat to public health, because it attracts vermin and acts as a breeding ground for bacteria.

This study therefore seeks to examine menace of waste dumping along the median strips ad drainages thereby finding out the causes and developing a new communication model to solving the issue.

\section{Research Questions}

$\mathbf{R Q}^{1}$ Why do residents dump refuse along medians strips and drainages and how enormous is the practice?

$\mathbf{R Q}^{\mathbf{2}}$ To what extent are residents aware of the statutory provision against waste dumping along the median strips and drainages and their consequences if such exist?

$\mathbf{R Q}^{\mathbf{3}} \quad$ To what extent are residents aware of the health and environmental consequences of drainages? waste dumping along median strips and

\section{Literature Review}

Waste is one of the constant production elements of human activities on earth, as the non-generation of waste is tantamount to nonexistence of man. Production of waste therefore, is as old as man. As described by Moronkola and Okanlawon [17], wastes are unwanted, discarded, non-liquid materials emanating from various activities of man at home, school and workplace which may be combustible. Similarly, Olanipekun, et al. [18] posit that wastes are rubbish or materials that are not needed and are economically unusable, without further processing. 
Demirbas [19] classified waste into three broad categories of solid, liquid and gaseous. Solid waste is any material, which is not in liquid form, and has no value to the person who is responsible for it [20-23]. Also Babayemi and Dauda [24] submitted that solid wastes is a non-liquid and nongaseous products of human activities, regarded as being useless. It could take the forms of refuse, garbage and sludge [25-30]. Secondly, liquid waste which can be discharged from various processes including industrial, mining, commercial, agricultural, medical and domestic in nature are also known as effluent [31-33]. Lastly gaseous wastes are elements carried in air which move without inhibition into any available space and may not be coloured [34]. They can be in form of vehicle exhaust, cooking smoke, cigarette or cigarette smoke, asbestos dust, discharge from factory chimneys or stacks, gas flaring [35].

Waste generation revolves around factors like life styles, food habits, living standards and the degree of urbanisation and industrialisation of people living in a community. Park (2007) identifies sources of waste to include: waste collected by scavenging; market waste; stable litter gotten from stables and industrial waste.

\subsection{Effect of Indiscriminate Waste Dumping}

Oyeniyi [9] points out that waste gotten from humans have severe ecological effects principally as a result of their aggregate nature, and their vast quantity. The environmental menace factors in disorganised waste dumping could lead to minor, severe infections and deaths. Explaining the environmental effect of wrong waste disposal, Rushton [36] noted that it gives rise to unpleasant smell which is dangerous to human existence as extreme intake of this contaminated air can lead to lungs obstruction as well as breathing challenges.

Ajero and Chigbo [37] further affirms that the effect of haphazard disposal of waste has been a bothersome health subject for decades. Describing the health effect of indiscriminate waste disposal, Park (2007) stated that indiscriminate waste disposal promote the breeding of arthropod-borne infections such as malaria diarrhoea, cholera among others.
Organic portion of waste, when fermented, according to Akindutire and Alebiosu [39] gives rise to flies breeding, hence depositing communicable substances on the skin. Ajayi [40] additionally notes that if an environment is infested with waste such as destroyed bottles, piles of harmful things, kids and grownups are susceptible to wounds which if not well managed woud result to tetanus infection.

Achalu and Achalu [41] in their study, revealed that indiscriminate waste disposal obstructs the free flow of floods during the rainy season, consequently leading to unnecessary destruction of lives and properties.

\subsubsection{Methods of Waste Collection}

Ajie [42] identified the following refuse collection methods:

Curb side Collection: This involves informing the people to throw their garbages at the curb side (road) on as collection day at a precise time to help collection at chosen time. In enforcing this, environment inspectors are appointed to issue penalties to those who forget their bin for too long.

Door to Door Collection: This is achieved by providing different waste containers for the inhabitants thereby informing them to separate their garbage as they throw them in. The containers are been emptied by the dumperplacer and refuse collectors and replaced on daily basis.

Block Collection: In this approach, collection vehicles have a designed route which it follows according to schedules. Individuals are expected to bring out their garbage to the vehicle for discharge.

\subsubsection{Development communication}

Researchers and scholars may differ in their definition of development communication, but their overall intent is central. The Development Communication Division of the World Bank defines development communication as an interdisciplinary field based on empirical research that helps to build consensus while it facilitates the sharing of knowledge to achieve positive change in development initiatives. It is not only about effective dissemination of 
information but also about using empirical research and two-way communication among stakeholders. Similar is the consensus definition reached at the First World Congress of Communication for Development, held in Rome in October 2006 which sees development communication as a social process based on dialog using a broad range of tools and methods. It is also about seeking a change at different levels, including listening, building trust, sharing knowledge and skills, building policies, debating, and learning for sustained and a meaningful change. It is not public relations or corporate communication.

Oftentimes communication is used to inform and persuade, as against using communication to engage stakeholders. As stated by Quarry and Ramirez [43], managers and decision makers want communication, but too often it is the first kind of communication. Mefalopulos [44] describes the information and persuasive action of communication as monologic communication, while the engaging aspect is referred to as dialogic communication.

Monologic approach involves a linear transmission of information, usually from a sender to many receivers. It is basically used when raising awareness [44, 45]. It adopts the various means of mediated communication to inform its communication to inform" typically involves a linear transmission of information, usually from a sender to many receivers. Its underlying assumption is that individual attitudes and behaviours can be changed voluntarily through communication and persuasion $[44,46]$.

Dialogic, on the other hand, is based on the horizontal, two-way model of communication, establishing a constructive environment where stakeholders participate in problem definitions and solutions [47-49]. Pruitt and Thomas [50] terms dialogic as a situation where participants come together in a safe space to understand each other's viewpoint in order to develop new options to address a commonly identified problem. The overall goal of the dialogic mode is to ensure mutual understanding and to make the best use of all possible knowledge in assessing the situation, building consensus, and looking for appropriate solutions.

\subsection{Theoretical framework}

\section{The Theory of Planned Behaviour}

The Theory of Planned Behaviour (TPB) utilises a cognitive method in explaining behaviour which focusses on beings' attitudes and beliefs. The TPB emerged from the theory of reasoned action [51] [52] which postulated intention to act as the best predictor of behaviour. TPB states that an individual's behavioural beliefs, control beliefs, normative beliefs correspondingly determine his/her attitude towards a given action, subjective norm, and perceived behavioural control. This collectively influences the behavioural intention and actual behaviour of the individual when participatory decisions in an action are voluntary and under an individual's control. Waste dumping culture of Ogun State residents along road media can be traced to this theoretical underpin, as the act of the people can be tied to firstly their developing belief of unstructured waste dumping is right.

\section{Research Methodology}

The study adopted the quantitative and qualitative research methodologies of indepth interview and survey. Survey on the one hand was used to find out the knowledge, attitude amd practices of randomly selected respondents who reside in both Idirko road in Ota Ogun State and Adatan/ Lafenwa road in Abeokuta Ogun State towards waste dumping along the median strips and drainages. the random sampling technique was employed in selecting the sample size of 150 respondents among resident who reside or transacts businesses along Idirko road in Ota and150 respondents among residents of Adatan/ Lafenwa road in Abeokuta Ogun state. The choice of selecting 300 respondent was in line with Comrey and Lee's (1992) parameter for selecting multivariate studies sample size. In his view, a sample size of " 50 is very poor; 100 is poor; 200 is fair; 300 is good; 500 is very good and 1000 is excellent"

On the other hand, in-depth interview methodology using structured interview questions was adopted in eliciting information on the communication strategy used by the Ogun State government by purposively selecting the secretary Ogun State Executive Council who also doubled as the permanent secretary cabinet matters. 


\section{Discussion of findings based on the research questions}

$\mathbf{R Q}^{1}$ Why do residents dump refuse along medians strips and drainages and how enormous is the practice?

To answer this question, the researcher conducted an in-depth interview with the Ogun State Permanent Secretary, Cabinet Matters, who also, as at the period of this study, is the Secretary to the Ogun State Executive Council. According to him, 'there is no justification for dumping waste along the median strip and drainages, except a display of personal uncleanliness. It shows some people are just irresponsible. No other reason, because you are supposed to get rid of your waste. It is just the height of indiscipline, because the government has provided waste disposal facilities.

Against the position of the Government representative, the survey conducted on residents of Ogun State as depicted in the figure 1 of the data presentation interestingly reveals that majority of the residents accept the wrongness in dumping of waste along the median strip and drainages as $43.8 \%$ of the sampled respondents disagreed with the poser that there is nothing wrong with dumping waste along the median strip and drainages. Defending the reason for their actions however, $54 \%$ of the respondents attributed it to the long distance of waste containers, $56.3 \%$ related their actions to non-availability of waste dump site. Although $55.2 \%$ of the sampled population stated that their actions was not an instruction from the Government, the study revealed that the act has developed into a norm, as $57.3 \%$ of the residents stated that they find it convenient. Similarly $52.1 \%$ declared that the act has become a normal practice to them. The residents' recognition that the wrongness of the practice despite being a growing norm, is further revealed in figure $2-4$, as $67.7 \%$ dump their waste during the night period, $71.9 \%$ dump it secretly, while $51.0 \%$ dump it once in a week.

It can therefore be inferred from the above that the non-availability of waste dumping containers and the distance to residents' abode is the major reason for the menace of waste dumping along the median strips and drainages. This is against the position of the government who believes it has provided enough waste dumping facilities. Also the survey reveals that the practice has developed into a norm, even though the residents perform this act at night period secretly.

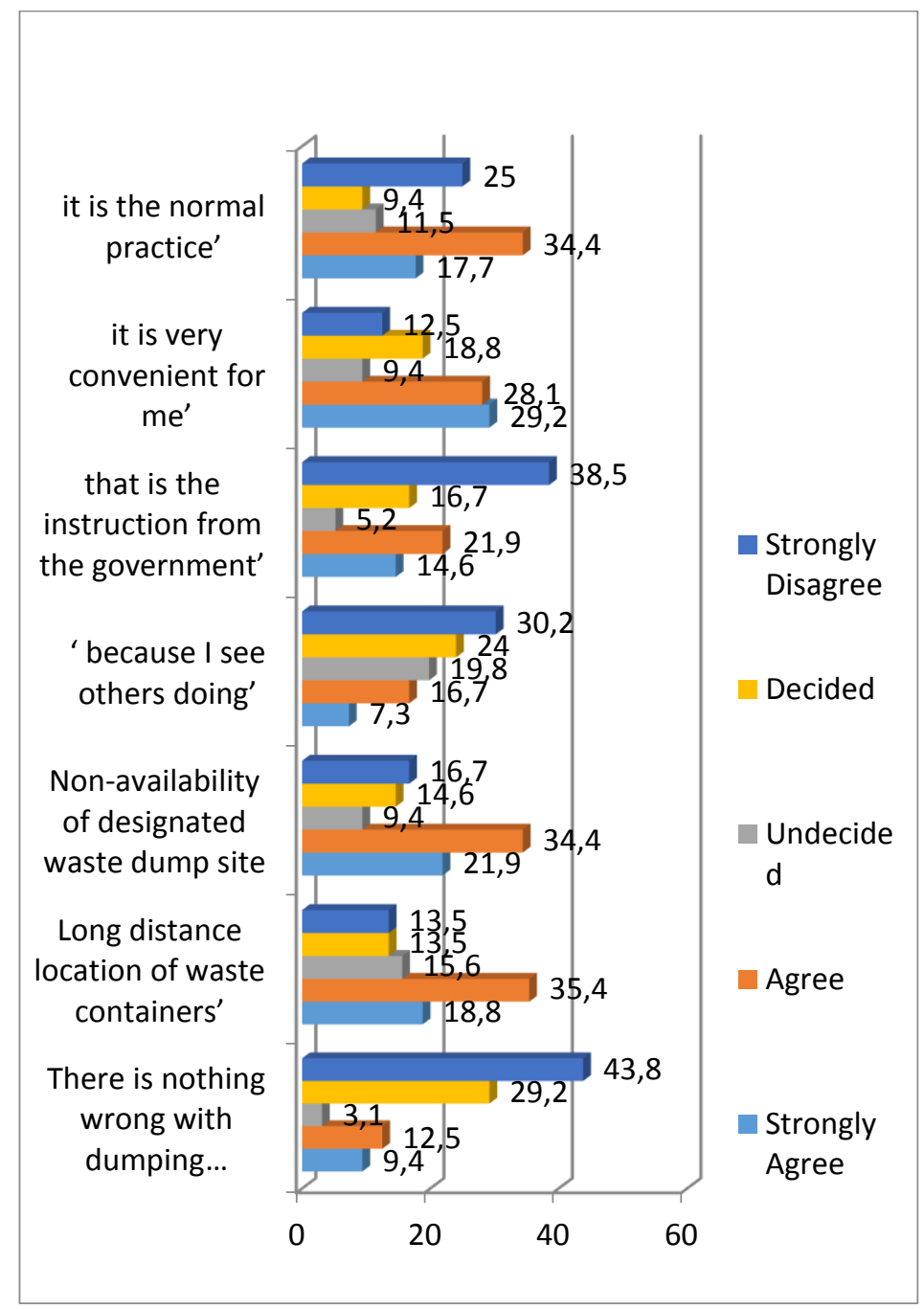

Figure 1: Chart showing the reasons for indiscriminate waste dumping 


\section{Waste dumping period}

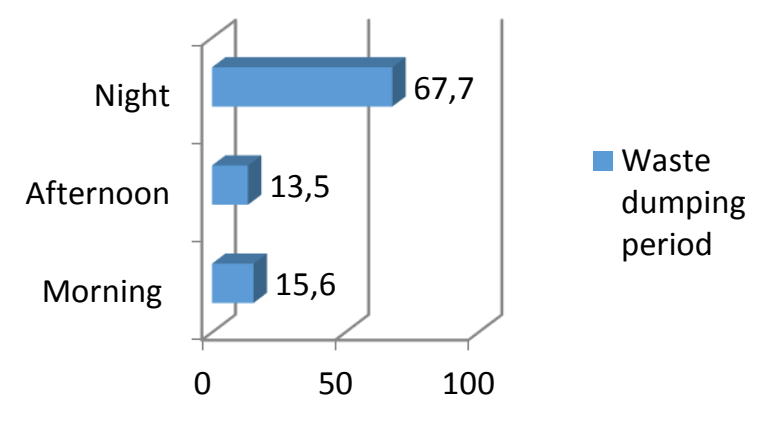

Fugure 2: Chart showing the period of waste dumping

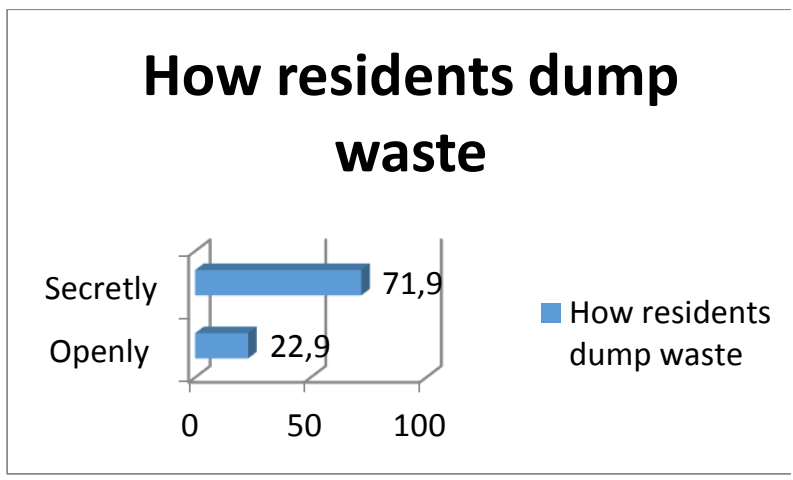

Figure 3: Chart showing how resident dump waste

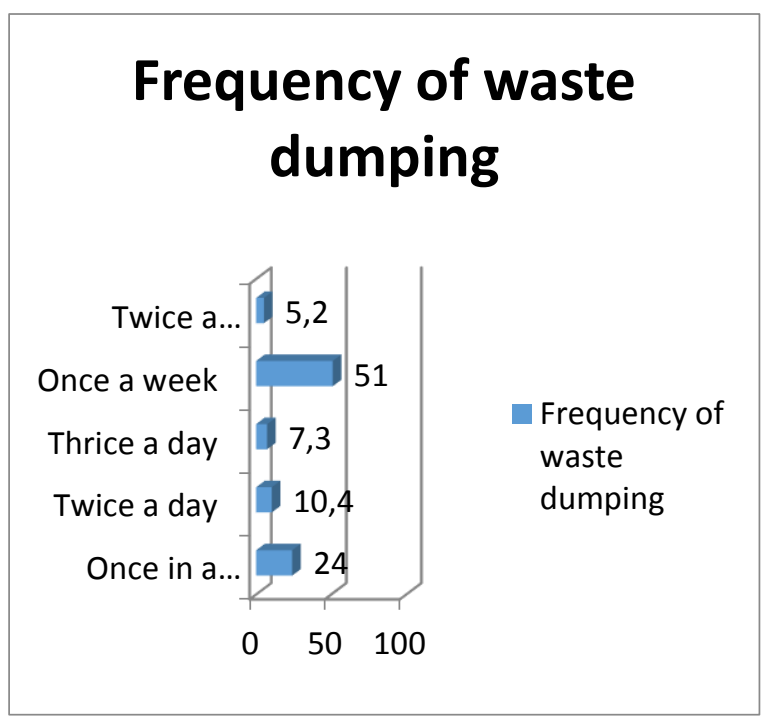

Figure 4: Chart showing the frequency of waste dumping

$\mathbf{R Q}^{2}$ To what extent are residents aware of the statutory provision against waste dumping along the median strips and drainages and their consequences if such exist?

The study according to figure 5 revealed that $80.2 \%$ of the sampled population expressed knowledge that there is a law against dumping of waste along median strips and drainages. Describing the punishment, $45.8 \%$ stated that the act will attract payment of fine, while $31.3 \%$ related the punishment to imprisonment. Relating the channels of their information as shown in figure $6,46.9 \%$ stated that they got informed through radio jingles, while 41.7 stated that they saw the campaign on the television. $59.4 \%$ in table 13 revealed that they hear/watch the jingle/campaign about the law against waste dumping along the median strip and drainages very often.

The researcher can therefore infer from the above that the residents have premonition that there is a consequent punishment against the act of dumping waste along the median strips and drainages.

\section{Awareness level of law against reckless...}

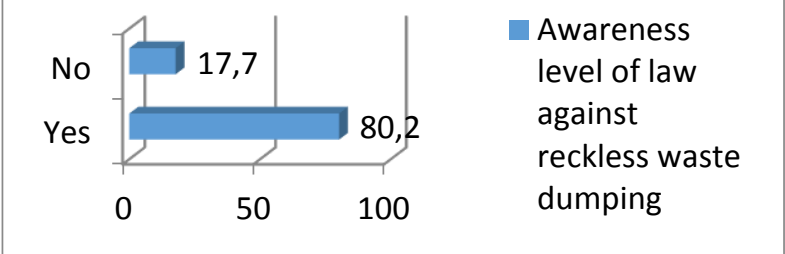

Figure 5: Chart showing the awareness level of law against waste dumping

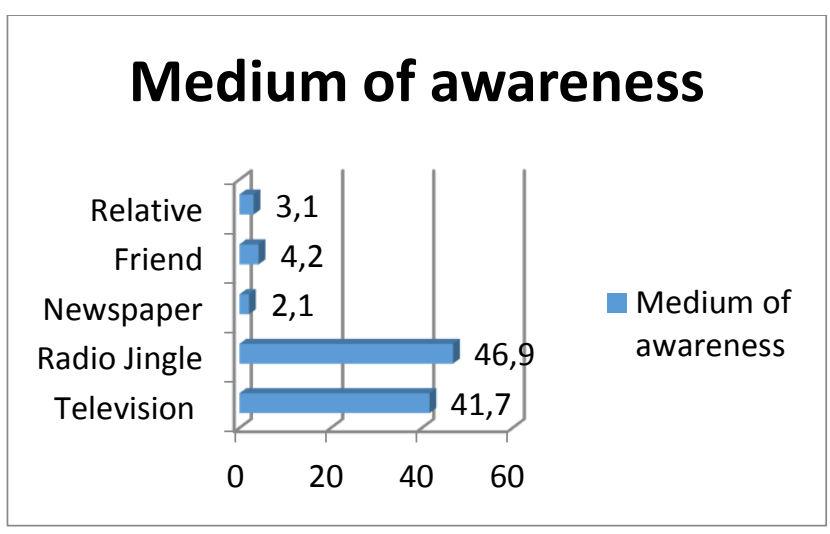

Figure 6: Medium of awareness 
$\mathbf{R Q}^{\mathbf{3}}$ To what extent are residents aware of the health and environmental consequences of drainages?

waste dumping along median strips and

The study as shown in figure 7 shows that Ogun State residents are fully aware of the health and environmental consequences of dumping waste along the median strips and drainages as $87.5 \%$, $89.6 \%, 91.7 \%, 83.3 \%, 90.6$ and $85.4 \%$ expressed that they are aware of the Diarrhoea, cholera. Malaria, flooding, pollution, and climate effects of the act of dumping waste along the median strip and drainages respectively.

Impliedly, the people are well informed that dumping of waste illicitly has both environmental and health negative consequence on their lives.

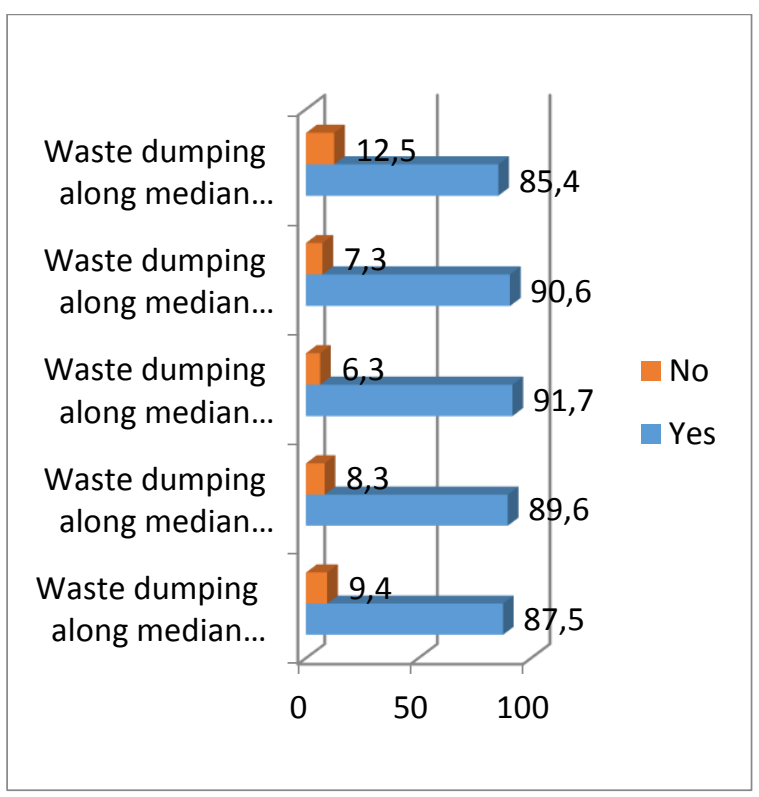

Figure 7: Chart showing residents level of awareness of health and environmental consequences

\section{Conclusion}

The menace of waste dumping along the median strip and drainages in Ogun state as evident in the finding has gone beyond an act to a norm, hence generating into behavioural issue. As Theory of Planned Behaviour states that an individual's behavioural beliefs, control beliefs, normative beliefs correspondingly determine his/her attitude towards a given action, subjective norm, and perceived behavioural control. As revealed in the study, non-availability of waste disposal facilities and the proximity of placement even when available is a major factor for this illicit act. This therefore is against the Ogun State government notion that the action of the people is unjustifiable. The residents seem to have no alternative means of waste disposal, more so that the residents are highly aware of the health and environmental consequences. Furthermore majority of the residents recognises that the act accompanied with a punishment of either payment of fine or imprisonment.

The study also evidently shows that the objective of the government communication against the act of waste dumping along the median strips and drainages is basically to inform and to persuade the audience using basically the broadcast and print media of communication. Since this menace has permeated into a norm level, the government needs to drastically change its communication approach to a participatory and dialogic approach. The government needs to come down to the level of the people by adopting the horizontal, "two-way" model, which favours people's active and direct interaction through consultation and dialog. This approach involves the functional participation approach as proposed by Mefalopulos (2008), a situation where stakeholders take part in predetermined objectives set by the project. This kind of participation, while it does not usually result in dramatic changes on "what" objectives are to be achieved, does provide valuable inputs on "how" to achieve them. Functional participation implies the use of horizontal communication among stakeholders (Mefalopulos, 2008). The government needs to make the people feel that it is a project to make for a cleaner and safer environment.

A need for an urgent shift from Mongolic to Dialogic communication in curbing the deepening behavioural pattern of dumping waste along the median strips and drainages by residents of Ogun State cannot be over emphasised at this period of time. Against the view of the government that even with no provision of waste disposal facilities, the act is unjustifiable, the people will not desist until the government makes the issue of environmental cleanliness a project of development communication, by not only informing or persuading, but engaging with the people on a participatory level. Hence, instilling a new culture of dumping the refuse in well provided and located waste disposal facilities should be a 
priority. As revealed in the study, the people recognise the wrongness and the many health and environmental consequences of the act. However they dump their refuse secretly at night. Also the use of forceful methods like imprisonment or payment of fine may not really nip the problem in the bud, the people must therefore be seen as stakeholders in the wheel of progress vision of the government, through participatory engagement.

\section{Recommendations}

Following the observations and findings from this study, the study therefore offers the following recommendations:

1. The government should communicate with the people through two way communication methods of town hall meetings, seminars and workshops.

2. Polythene Waste disposal containers should be made available for every household, even if it is going to be purchased.

3. Opinion leaders through Community Development Associations (CDA) should be given additional roles to play in ensuring environmental cleanliness by engaging with their residents.

\section{References}

[1] P. Oluwande, Guide to tropical environmental health and engineering: Nigerian Institute of Social and Economic Research, 1983.

[2] O. Oyelola and A. Babatunde, "Effect of municipal solid waste on the levels of heavy metals in Olusosun dumpsite soil, Lagos State, Nigeria," International Journal of Pure and Applied Sciences, vol. 2, pp. 17-21, 2008.

[3] K. Donevska, M. Jovanovski, A. Efremov, and J. Papic, "Impact Assessment of the Solid Waste Landfill in the Municipality of Centar Zupa," in Conference on water observation and information system for decision support, Balwois, 2006, pp. 23-26.

[4] A. J. McMichael, "The urban environment and health in a world of increasing globalization: issues for developing countries," Bulletin of the World Health Organization, vol. 78, pp. 1117-1126, 2000.

[5] M. Adetunji and O. Oyeleye, "Evaluation of the Causes and Effects of Flood in Apete, Ido Local Government Area, Oyo State, Nigeria," Evaluation, vol. 3, 2013.

[6] O. Abolade, A. B. Muili, and S. A. Ikotun, "Impacts of flood disaster in Agege local government area Lagos, Nigeria," International Journal of Development \& Sustainability, vol. 2, pp. 2354-2367, 2013.

[7] O. Omojola, "Using Symbols and Shapes for Analysis in Small Focus Group Research," Qualitative Report, vol. 21, 2016.

[8] C. Ezugwu, "New Approaches to Solid Waste Management," in Proceedings of the World Congress on Engineering and Computer Science, 2015.

[9] B. A. Oyeniyi, "Waste management in contemporary Nigeria: the Abuja example," International Journal of Politics and Good Governance, vol. 2, pp. 1-18, 2011.

[10] A. Taiwo, "Waste management towards sustainable development in Nigeria: A case study of Lagos tate," International NGO Journal, vol. 4, pp. 173-179, 2009.

[11] S. Oloyede, C. Ayedun, O. Durodola, and N. J. Peter, "Residential Solid Waste Management in Sango-Ota, Ogun State: To Recycle or Not to Recycle?," Research on Humanities and Social Sciences, vol. 4, pp. 189194, 2014.

[12] B. A. Odufuwa, B. O. Odufuwa, O. M. Ediale, and S. Oriola, "Household Participation in Waste Disposal and Management in ljebuOde, Nigeria," Journal of Human Ecology, vol. 40, pp. 247-254, 2012.

[13] O. Odiboh, A. Olonode, E. Adesina, and D. Yartey, "Influence of e-communication and digital culture on Nigeria's indigenous sociocultural systems: A focus on Abeokuta and Ota, Nigeria," in 2018 4th International Conference on Information Management (ICIM), 2018, pp. 71-75.

[14] D. Ogbonna, G. Amangabara, and T. Ekere, "Urban solid waste generation in Port Harcourt metropolis and its implications for waste management," Management of Environmental Quality: An International Journal, vol. 18, pp. 71-88, 2007.

[15] T. Karak, R. Bhagat, and P. Bhattacharyya, "Municipal solid waste generation, composition, and management: the world scenario," Critical Reviews in Environmental Science and Technology, vol. 42, pp. 1509-1630, 2012. 
[16] A. Evaristus, O. Olusola, O. Nelson, A. Lanre, A. Babatunde, and Y. Darlynton, "Data on information sources, knowledge and practice on Hepatitis b virus in Southwest Nigeria," Data in brief, 2020.

[17] O. Moronkola and F. Okanlawon, "Fundamentals of public and community health education," Ibadan Royal People, 2003.

[18] J. Olanipekun, P. Oyeniyi, and P. Konwea, "Assessment of Solid Waste Management Techniques in Ekiti State Urban Area," Nigeria School Health Journal, vol. 19, pp. 75-82, 2007.

[19] A. Demirbas, "Waste management, waste resource facilities and waste conversion processes," Energy Conversion and Management, vol. 52, pp. 1280-1287, 2011.

[20] A. V. Shekdar, "Sustainable solid waste management: an integrated approach for Asian countries," Waste management, vol. 29, pp. 1438-1448, 2009.

[21] A. M. Troschinetz and J. R. Mihelcic, "Sustainable recycling of municipal solid waste in developing countries," Waste management, vol. 29, pp. 915-923, 2009.

[22] E. Adesina, O. Oyero, N. Okorie, L. Amodu, B. Adeyeye, F. Omole, et al., "Assessment of health communication practice on hepatitis B in Southwest Nigeria," Cogent Social Sciences, vol. 6, p. 1777814, 2020.

[23] O. Omojola, L. Amodu, N. Okorie, D. Imhonopi, D. Yartey, and E. Adesina, "Assessing the One-Lecture-One-Test Learning Model in Undergraduate Journalism Program Using Cohort Design," The Journal of Social Sciences Research, vol. 4, pp. 591-597, 2018.

[24] J. Babayemi and K. Dauda, "Evaluation of solid waste generation, categories and disposal options in developing countries: a case study of Nigeria," Journal of Applied Sciences and Environmental Management, vol. 13, 2009.

[25] T. Leton and O. Omotosho, "Landfill operations in the Niger delta region of Nigeria," Engineering Geology, vol. 73, pp. 171177, 2004.

[26] U. Suleimanu, N. Okorie, O. Bamgboye, L. Amodu, F. Afolabi, and E. Adesina, " Internet, social media and computer-mediated relationship among engineering undergraduate students," International
Journal of Civil Engineering and Technology, vol. 9, pp. 1651-1657, 2018.

[27] N. Okorie, L. Amodu, A. Jegede, E. Adesina, and O. Martins, "Global Media, Digital Journalism and the Question of Terrorism: An Empirical Inquest on ISIS," Media Watch, vol. 10, pp. 212-224, 2019.

[28] L. Amodu, O. Omojola, N. Okorie, B. Adeyeye, and E. Adesina, "Potentials of Internet of Things for effective public relations activities: Are professionals ready?," Cogent Business \& Management, vol. 6, p. 1683951, 2019.

[29] B. Adeyeye, L. Amodu, O. Oscar, O. Omojola, E. Adesina, and C. A. Ben-Enukora, "A SWOT Analysis of Indigenous Language Use in Agricultural Radio Programming in Nigeria," in Emerging Trends in Indigenous Language Media, Communication, Gender, and Health, ed: IGI Global, 2020, pp. 188-209.

[30] E. Adesina, O. Odiboh, O. Oyero, B. Adeyeye, D. Yartey, and T. Ekanem, "Publishing African communication researches in open access outlets: An interrogation of Scopus between 1996-2016 " in 31st IBIMA Conference, Milan, Italy, 2018, pp. 6340-6345.

[31] W. C. Blackman Jr, Basic hazardous waste management: Crc Press, 2016.

[32] E. Adesina, O. Oyero, N. Okorie, O. Omojola, L. Amodu, and B. Adeyeye, "Health management strategies for hepatitis care practices: An interplay of communication structures and social marketing theory," in 32nd International Business Information Management Association Conference, ville, Spain, 2018, pp. 7305 -7309.

[33] B. Adeyeye, L. Amodu, O. Odiboh, N. Okorie, E. Adesina, D. Yartey, et al., "Data on new media use for agricultural training and research at Agricultural Services and Training Centre (ASTC)," Data in Brief, vol. 22, pp. 181184, 2019.

[34] A. Igoni, M. Ayotamuno, S. Ogaji, and S. Probert, "Municipal solid-waste in Port Harcourt, Nigeria," Applied Energy, vol. 84, pp. 664-670, 2007.

[35] A. A. Mbina and E. E. Edem, "Challenges of urban waste management in Uyo Metropolis, Nigeria," waste management, vol. 7, 2015.

[36] L. Rushton, "Health hazards and waste management," British medical bulletin, vol. 68, pp. 183-197, 2003. 
[37] C. Ajero and U. Chigbo, "A study on the evaluation of industrial solid waste management approaches in some industries in Aba, South Eastern Nigeria," West African Journal of Industrial and Academic Research, vol. 4, pp. 103-112, 2012.

[38] K. Park, "Park's textbook of preventive and social medicine," 2007.

[39] I. Akindutire and E. Alebiosu, "Environmental Risk Factors of Indiscriminate Refuse Disposal in Ekiti State, Nigeria," IOSR Journal of Research and Method in Education, vol. 4, pp. 54-59, 2014.

[40] F. Ajayi, "A guide to primary health care Practice in developing Countries," ed: Akure: Benduny Grafiks, 2005.

[41] E. Achalu and O. Achalu, "Environmental health and pollution control," Lagos: Simarch Nigeria Limited, Lagos, pp. 1-6, 2004.

[42] U. E. Ajie, Dienye, A., Spatial data analysis of solid waste management system in Port Harcourt metropolis after 100 years of its existence. Kuala Lumpur,: FIG (International Federation of Surveyors), 2014.

[43] W. Quarry and R. Ramirez, Communication for another development: Listening before telling: Zed Books Ltd., 2013.

[44] P. Mefalopulos, Development communication sourcebook: Broadening the boundaries of communication: World Bank Publications, 2008.

[45] L. Mitchell, "Development Communication Sourcebook: Broadening the Boundaries of Communication," The European Journal of Development Research, vol. 21, pp. 675-676, 2009.
[46] J. Servaes, Communication for development: One world, multiple cultures: Hampton Press (NJ), 1999.

[47] S. Rybalko and T. Seltzer, "Dialogic communication in 140 characters or less: How Fortune 500 companies engage stakeholders using Twitter," Public relations review, vol. 36, pp. 336-341, 2010.

[48] Adesina, N. Okorie, O. Oyero, B. Adeyeye, and K. Oyesomi, "Media reportage and audience perception of hepatitis disease in Nigeria," Global Journal of Health Science, vol. 9, p. 68, 2017.

[49] E. Adesina, O. Oyero, N. Okorie, C. BenEnukora, and B. Adeyeye, "Risk communication for viral hepatitis management among migrants," in Handbook of Research on the Global Impact of Media on Migration Issues, ed: IGI Global, 2020, pp. 235-252.

[50] B. Pruitt and P. Thomas, "Democratic dialogue-A handbook for practitioners," New York: United Nations Development Program, 2006.

[51] M. Fishbein and I. Ajzen, "Belief, attitude, intention and behavior: An introduction to theory and research," Journal of Business Venturing vol. 5, pp. 177-189, 1975. [52] D. Albarracin, B. T. Johnson, M. Fishbein, and P. A. Muellerleile, "Theories of reasoned action and planned behavior as models of condom use: a meta-analysis," Psychological bulletin, vol. 127, pp. 142-161, 2001.

\section{Creative Commons Attribution License 4.0 (Attribution 4.0 International, CC BY 4.0)}

This article is published under the terms of the Creative Commons Attribution License 4.0

https://creativecommons.org/licenses/by/4.0/deed.en_US 